\title{
A 19th Century Caddo Component at the Gatlin Site (41RK1) in the Angelina River Basin of East Texas
}

Timothy K. Perttula

Heritage Research Center, Stephen F. Austin State University

Follow this and additional works at: https://scholarworks.sfasu.edu/ita

Part of the American Material Culture Commons, Archaeological Anthropology Commons, Environmental Studies Commons, Other American Studies Commons, Other Arts and Humanities Commons, Other History of Art, Architecture, and Archaeology Commons, and the United States History Commons

Tell us how this article helped you.

This Article is brought to you for free and open access by the Center for Regional Heritage Research at SFA ScholarWorks. It has been accepted for inclusion in Index of Texas Archaeology: Open Access Gray Literature from the Lone Star State by an authorized editor of SFA ScholarWorks. For more information, please contact cdsscholarworks@sfasu.edu. 


\section{A 19th Century Caddo Component at the Gatlin Site (41RK1) in the Angelina River Basin of East Texas}

\section{Creative Commons License}

\section{(c) (1) \&}

This work is licensed under a Creative Commons Attribution-NonCommercial 4.0 International License 


\title{
A $19^{\text {th }}$ Century Caddo Component at the Gatlin Site (41RK1) in the Angelina River Basin of East Texas
}

\author{
Timothy K. Perttula
}

The Gatlin site (41RK1) is located ca. 1 mile to the southeast of the small community of Mount Enterprise in Rusk County in the headwaters of the Angelina River basin in the East Texas Pineywoods (Diggs et al. 2006: Figure 41). The site was first investigated by the landowner in about 1895 (Records on file at the Texas Archeological Research Laboratory [TARL], The University of Texas at Austin). At that time, the landowner exposed a single burial with preserved skeletal remains and two extra skulls in the burial pit; each of the skulls supposedly had a hole (bullet hole?) on one side of the head. Among the funerary offerings reported to have been found by the landowner were arrow points, pottery vessels, a pistol, and a rifle barrel. These findings suggest that the burial dates to historic times and, because of the inclusion of the pottery vessels and arrow points, the find was probably the burial of a Caddo Indian.

In September 1935, A. T. Jackson of The University of Texas at Austin returned to the site area to attempt to locate a Caddo cemetery and recover whole vessels for the university collections (Guy 1990:Table 3; Story and Creel 1982:Table 3). His excavations were unsuccessful in locating any burials, but he did identify a habitation/midden deposit at the site about $50 \mathrm{~m}$ west of a mineral spring, on a hillside (TARL files). These deposits were ca. $20 \mathrm{~cm}$ in thickness and consisted of broken animal bones, mussel shell fragments, pieces of lithic debris, aboriginal and European-made pottery vessel sherds, a few small pieces of bottle glass, and a fragment of a brass kettle. These finds also suggest that the habitation/midden deposit dates to historic times, although when during the historic period was uncertain because the collections have not been studied in any detail since they were recovered in 1935 .

\section{COLLECTIONS FROM THE SITE}

In the course of working in 2008 on the analysis of Caddo ceramic assemblages in the TARL collections from the Neches and Angelina River basins, I had the opportunity to examine and analyze the small collection of artifacts recovered by A. T. Jackson from the Gatlin site midden. This collection includes a small amount of aboriginal pottery, European vessel sherds, bottle glass, and a brass kettle fragment that were found together in a habitation/ midden deposit.

\section{Caddo Pottery}

Including one sandy paste Goose Creek Plain, var. unspecified body sherd (cf. Story 1990:277) ${ }^{1}$, there are seven aboriginal pottery sherds in the Gatlin site collection. Six of the sherds are from at least four different Caddo pottery vessels, based on differences in temper, paste, and firing conditions.

One bone-tempered jar (represented by a rim and body sherd) is horizontally brushed on the rim and has vertical brushing on the body with a row of circular punctates pushed through the brushing. The rim is $7.1 \mathrm{~mm}$ in thickness, with a rounded and exterior folded lip; the body sherd is $8.5 \mathrm{~mm}$ thick. The jar was fired and cooled in a low oxygen environment. The second jar is represented by a bonehematite-tempered body sherd from an incompletely oxidized vessel with parallel brushing marks.

The third vessel fragment from the Gatlin site includes two plain body sherds with bone-grog temper and a sandy paste; the vessel was fired in a low oxygen or reducing environment. These body sherds range from $5.0-7.9 \mathrm{~mm}$ in thickness. The last vessel is represented by a single plain bone-tempered body sherd ( $6.0 \mathrm{~mm}$ in thickness); it came from a vessel fired in an oxidizing environment.

In sum, all four vessels are bone-tempered, and those that have decorations have been brushed and brushed-punctated. The Caddo ceramic technology and decorative styles documented at the Gatlin site suggests that the closest affiliations of the Caddo group that lived there and made and used the pottery 
are with other Caddo sites and communities in the Angelina river basin (Perttula 2008:Figure 12-3). This same broad area of East Texas was occupied in historic times by numerous Caddo groups that were affiliated with the Hasinai Caddo (cf. Swanton 1942), including the Nasoni, Nadaco, Hainai, and Nacogdoche. The prehistoric Caddo settlers at the Gatlin site shared a common ceramic heritage with other prehistoric and historic Caddo groups living in this part of East Texas. The site lies near the center of this East Texas ceramic tradition. In areas where archaeological investigations have been undertaken in this East Texas area, brushed pottery is an important decorative component in the utility wares after ca. A.D. 1250 , and the proportion of brushed pottery appears to increase through time, on into the historic era. Caddo sites in these areas also have high proportions of burned bone used as temper.

\section{European Pottery}

The European pottery sherds $(n=46)$ from the Gatlin site appears to be from late $18^{\text {th }}$-early $19^{\text {th }}$ century refined earthenware vessels made in England. In addition to five unidentifiable refined earthenware sherds that have been burned (including four plain body sherds and one sherd with a blue hand-painted line), there are 16 sherds of pearlware (ca. 1780 to ca. 1830 ) and 25 whiteware (ca. post1830 ) sherds in the collection.

The pearlware sherds include two undecorated body sherds and a plain base from a plate as well as a body sherd of mocha ware (cf. Rickard 1993), three blue floral hand-painted rim and body sherds (including an embossed rim) (Figure 1e, g, i), three light to dark blue transfer-printed body sherds (Figure 1b, f, h), and five blue or green shell-edged rim and body sherds. The one green pearlware shell-edged sherd has an even scalloped rim with impressed straight lines and an impressed bud motif (Figure 2c). Miller and Hunter (1990) and Hunter and Miller (1994) indicate that this shell-edged motif was in use from $1800-1840$. The three blue shelledged rims (Figure 2a-b) also have an even scallop and impressed straight lines (1805-1830).

Among the whiteware sherds from the Gatlin site, there are four plain body, two plain rim, and one plain base sherd, and the remainder are decorated pieces. These include blue shell-edged $(n=1)$, blue floral hand-painted rims ( $n=2)$ (see Figure 1a), blue-red-green hand-painted body sherds $(n=4)$, and 11 transfer-printed sherds. These sherds are from plates with purple ( $n=1$, body sherd), red ( $n=4$, body sherds) (see Figure 1c-d), light blue ( $\mathrm{n}=4$, two rims and two body sherds), and blue ( $\mathrm{n}=2$, both rims) prints, the latter including a continuous repeating floral motif (1820-1836, see Samford 2000) with a scalloped and embossed rim (see Figure 2d-e). Samford's (2000:Table 5) information on the date ranges for the production of printed wares, particularly the mean beginning and end dates of production, suggests that the transfer-printed sherds from the Gatlin site date from ca. 1820-1840.

\section{Bottle Glass}

The one bottle glass sherd from the Gatlin site is an olive green sherd from an English wine bottle.

\section{Brass Kettle}

There is a single piece of a 3-legged brass kettle in the TARL collections from the site. The piece is a rim fragment with a single visible rivet.

\section{CONCLUSIONS}

The archaeological materials recovered by $\mathrm{A}$. T. Jackson from the Gatlin site in 1935 suggest that they are the product of a ca. 1800-1830s Caddo occupation. The estimated age of the site is based primarily on the kinds of European pottery found there, but the Caddo pottery sherds identified at the Gatlin site are consistent in character with the sorts of pottery found on Historic Caddo sites in the southern part of Rusk County and much of Nacogdoches County in the Angelina River basin. The evidence from the Gatlin site suggests that the Caddo continued to make and use traditional forms and styles of pottery in the early $19^{\text {th }}$ century, even as they began to adopt and regularly use massproduced European commodities that they obtained from Anglo-American traders.

Nineteenth century Caddo archaeological sites are very rare in East Texas, and only a small handful are known, among them Timber Hill (Parsons et al. 2002) and $41 \mathrm{HS} 840$, a ca. 1830 s Caddo village. This dearth of Caddo sites of $19^{\text {th }}$ century age is presumably the result of several factors, including that (1) Caddo populations were small-around 1000 individuals in East Texas in the late 1820s (see Ewers 1969) - and were continuing to decrease in size because of the effects of introduced European 


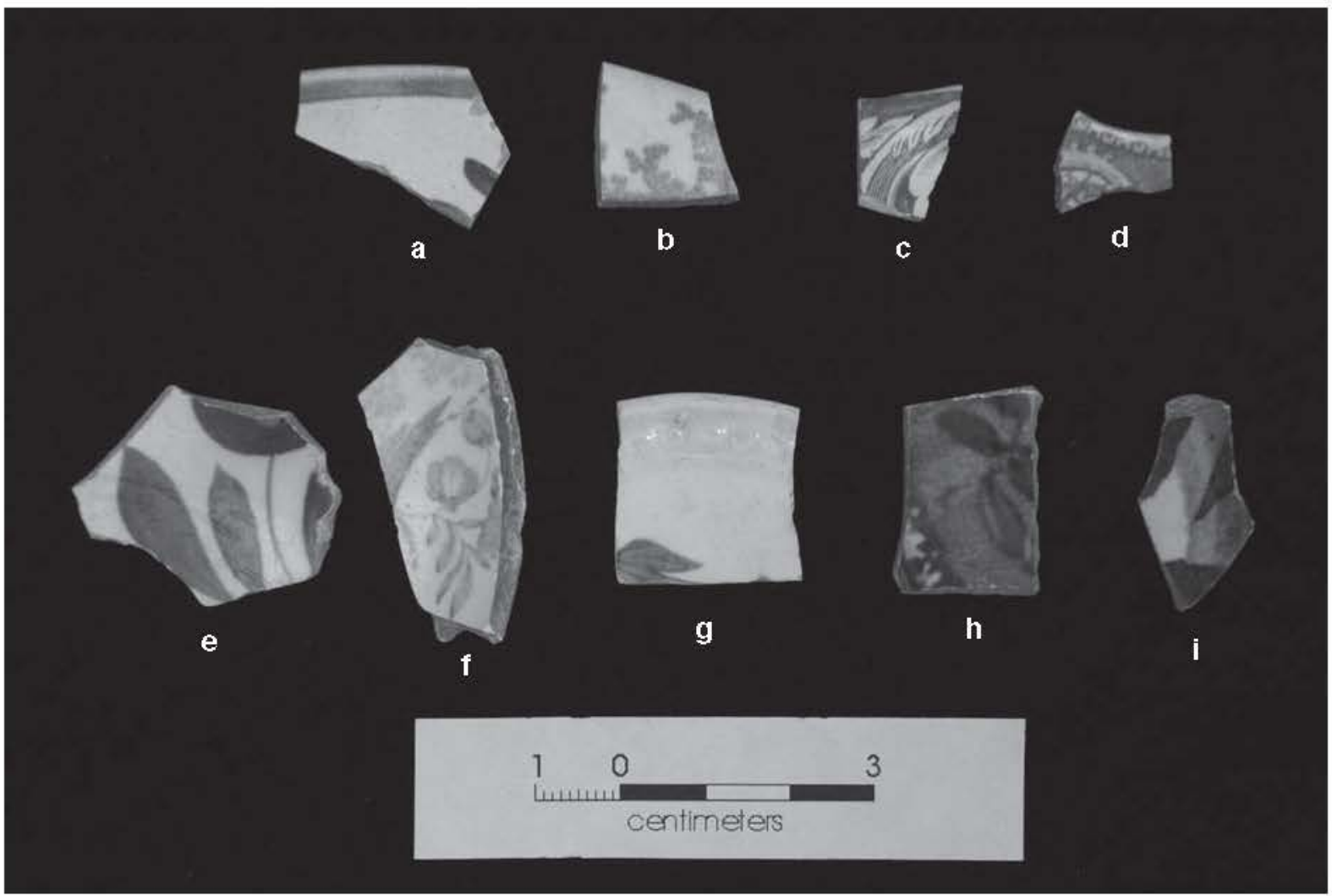

Figure 1. Decorated refined earthenwares at the Gatlin site: a, e, g, i, hand-painted; b, f, h, blue transfer-printed; c-d, red transfer-printed.

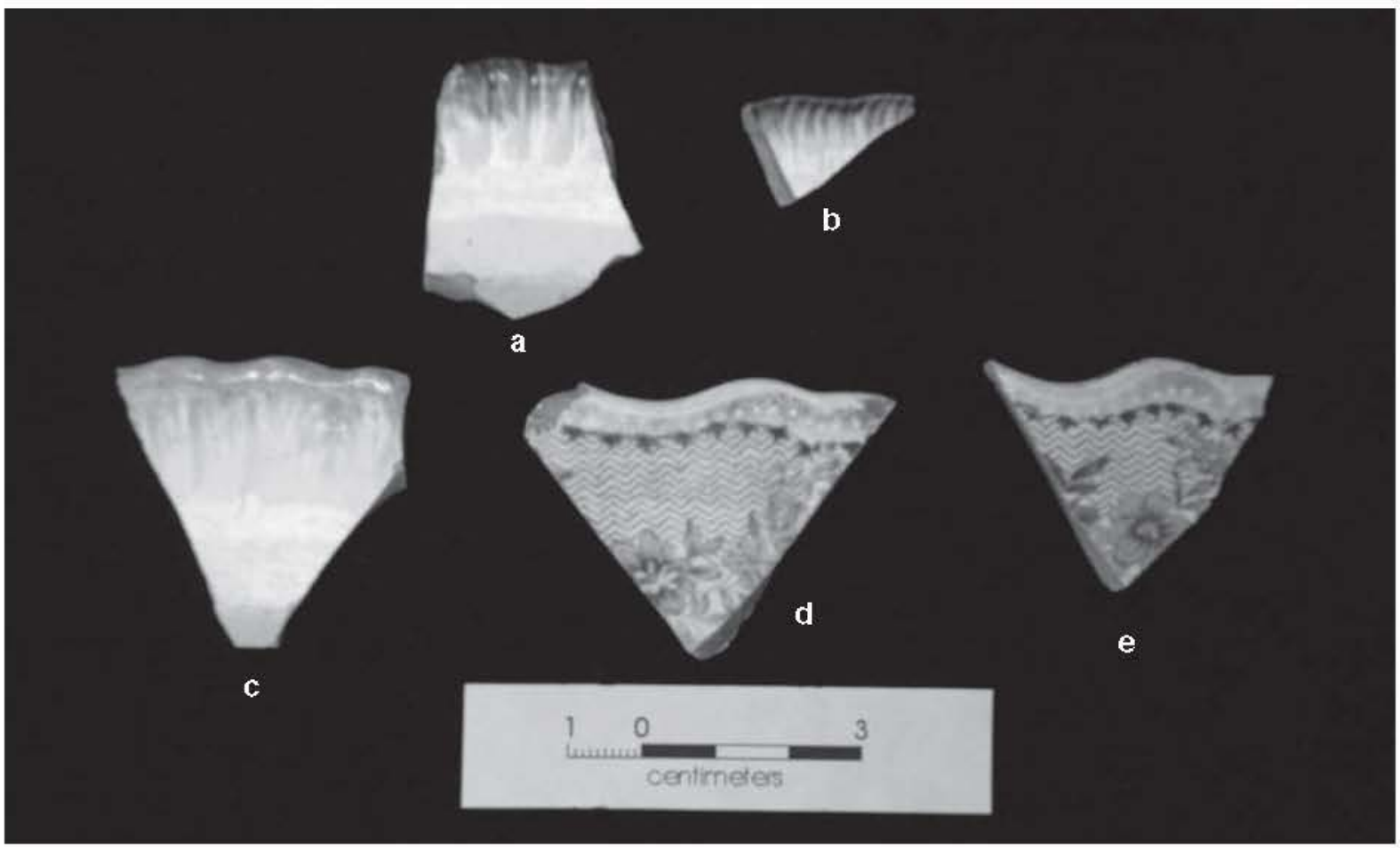

Figure 2. Shell-edged and transfer-printed refined earthenwares at the Gatlin site: a-b, blue shell-edged; $c$, green shelledged; d-e, blue transfer-printed. 
diseases, and (2) the increased mobility of Caddo groups who were attempting to live in an area that was gradually being overrun and settled by AngloAmericans from the United States that were moving into what was the Mexican province of Texas. Caddo groups did not have the luxury to remain long in permanent settlements, especially after 1835 , because of the land-grabbing tendencies of these new settlers, and the shorter the span of occupation at each settlement, the less archaeological materials would be left behind that archaeologists could even locate, were they looking for early $19^{\text {th }}$ century Caddo settlements.

Who were these Caddo that lived at the Gatlin site in such tumultuous times? The meager archaeological evidence only suggests that they were an Hasinai Caddo group. However, the Gatlin site is not far from the location of $18^{\text {th }}$ century Nasoni Caddo settlements on the upper Angelina River.

\section{END NOTE}

1. The Goose Creek Plain sherd is indicative of a pre-A.D. 800 Woodland period Mossy Grove culture occupation at the Gatlin site (Story 1990:277-278).

\section{ACKNOWLEDGMENTS}

Shawn Marceaux provided digital images of the two figures in the article.

\section{REFERENCES CITED}

Diggs, G. M., Jr., B. L. Lipscomb, M. D. Reed, and R. J. O'Kennon

2006 Illustrated Flora of East Texas, Volume One: Introduction, Pteridophytes, Gymnosperms, and Monocotyledons. Botanical Research Institute of Texas, Fort Worth.

Ewers, J. C. (editor)

1969 The Indians of Texas in 1830 by Jean Louis Berlandier. Smithsonian Institution Press, Washington, D.C.

Guy, J. A.

1990 Previous Archeological Investigations. In The Archeology and Bioarcheology of the Gulf Coastal Plain, by D. A. Story, J. A. Guy, B. A. Burnett, M. D. Freeman, J. C. Rose, D. G. Steele, B. W. Olive, and K. J. Reinhard, pp. 27-130. Research Series No. 38. Arkansas Archeological Survey, Fayetteville.

Hunter, R. R., Jr. and G. L. Miller

1994 English shell-edged earthenware. Antiques CXLV (no. 3):432-443

Miller, G. L. and R. R. Hunter, Jr.

1990 English Shell Edged Earthenware: Alias Leeds Ware, Alias Feather Edge. $35^{\text {th }}$ Annual Wedgwood International Seminar, pp. 107-136.

Parsons, M. L., J. E. Bruseth, J. Bagur, S. E. Goldborer, and C. McCrocklin

2002 Finding Sha'chahdinnih (Timber Hill): The Last Village of the Kadohadacho in the Caddo Homeland. Archeological Reports Series No. 3. Texas Historical Commission, Austin.

Perttula, T. K. (editor)

2008 Lake Naconiche Archeology, Nacogdoches County, Texas: Results of the Data Recovery Excavations at Five Prehistoric Archeological Sites. 2 Vols. Report of Investigations No. 60. Archeological \& Environmental Consultants, LLC, Austin.

Rickard, J.

1993 Mocha ware: Slip-decorated refined earthenware. Antiques CXLIV (no. 2):182-189.

Samford, P. M.

2000 Response to a Market: Dating English Underglaze Transfer-Printed Wares. In Approaches to Material Culture Research for Historical Archaeologists, compiled by D. R. Brauner, pp. 56-85. $2^{\text {nd }}$ Edition. The Society for Historical Archaeology, California, Pennsylvania.

Story, D. A.

1990 Cultural History of the Native Americans. In The Archeology and Bioarcheology of the Gulf Coastal Plain, by D. A. Story, J. A. Guy, B. A. Burnett, M. D. Freeman, J. C. Rose, D. G. Steele, B. W. Olive, and K. J. Reinhard, pp. 163-366. Research Series No. 38. Arkansas Archeological Survey, Fayetteville.

Story, D. A. and D. G. Creel

1982 The Cultural Setting. In The Deshazo Site, Nacogdoches County, Texas, Volume 1: The Site, Its Setting, Investigation, Cultural Features, Artifacts of Non-Native Manufacture, and Subsistence Remains, edited by D. A. Story, pp. 20-34. Texas Antiquities Permit Series, No. 7. Texas Antiquities Committee, Austin.

Swanton, J. R.

1942 Source Material on the History and Ethnology of the Caddo Indians. Bulletin 132. Smithsonian Institution, Bureau of American Ethnology, Washington, D.C. 